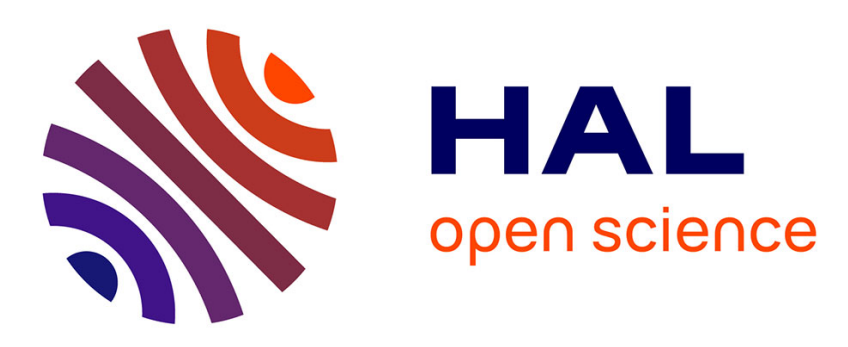

\title{
Impact of durum wheat milling on the deoxynivalenol distribution in the outcoming fractions
}

Gisella Rios, Nadine Zakhia-Rozis, Marc Chaurand, Florence Richard-Forget, Marie-Françoise Samson, Joel Abecassis, Valérie Lullien-Pellerin

\section{- To cite this version:}

Gisella Rios, Nadine Zakhia-Rozis, Marc Chaurand, Florence Richard-Forget, Marie-Françoise Samson, et al.. Impact of durum wheat milling on the deoxynivalenol distribution in the outcoming fractions. Food additives \& contaminants. Part A. Chemistry, analysis, control, exposure \& risk assessment, 2009, 26 (04), pp.487-495. 10.1080/02652030802382717 . hal-00577326

\section{HAL Id: hal-00577326 \\ https://hal.science/hal-00577326}

Submitted on 17 Mar 2011

HAL is a multi-disciplinary open access archive for the deposit and dissemination of scientific research documents, whether they are published or not. The documents may come from teaching and research institutions in France or abroad, or from public or private research centers.
L'archive ouverte pluridisciplinaire HAL, est destinée au dépôt et à la diffusion de documents scientifiques de niveau recherche, publiés ou non, émanant des établissements d'enseignement et de recherche français ou étrangers, des laboratoires publics ou privés. 


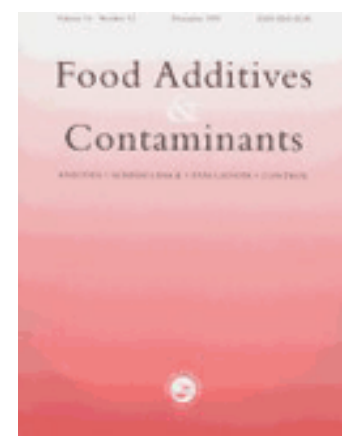

\section{Impact of durum wheat milling on the deoxynivalenol distribution in the outcoming fractions}

\begin{tabular}{|r|l|}
\hline Journal: & Food Additives and Contaminants \\
\hline Manuscript ID: & TFAC-2008-095.R1 \\
\hline Manuscript Type: & Original Research Paper \\
\hline Author: & 25-Jul-2008 \\
\hline Complete List of Authors: & $\begin{array}{l}\text { RIOS, Gisella; INRA, UMR 1208 IATE } \\
\text { ZAKHIA-ROZIS, Nadine; CIRAD, UMR 1208 IATE } \\
\text { CHAURAND, MARC; INRA, UMR 1208 IATE } \\
\text { RICHARD-FORGET, Florence; INRA, UR 1264 } \\
\text { SAMSON, Marie-Françoise; INRA, UMR 1208 IATE } \\
\text { ABECASSIS, JOEL; INRA, UMR 1208 IATE } \\
\text { LULLIEN-PELLERIN, Valérie; INRA, UMR 1208 IATE }\end{array}$ \\
\hline Methods/Techniques: & Chromatography - HPLC, Traceability \\
\hline Additives/Contaminants: & Mycotoxins \\
\hline Food Types: & Cereals and grain \\
\hline
\end{tabular}

\section{SCHOLARONE Manuscripts}


1 Impact of durum wheat milling on the deoxynivalenol distribution in the out-

\section{2 coming fractions}

3

4 G. RÍOS ${ }^{\mathrm{a}}$, N. ZAKHIA-ROZIS ${ }^{\mathrm{b}}$, M. CHAURAND ${ }^{\mathrm{a}}$, F. RICHARD-FORGET ${ }^{\mathrm{c}}$, M.F. SAMSON $^{\mathrm{a}}$, J. $5 \quad$ ABECASSIS $^{\mathrm{a}} \&$ V. LULLIEN-PELLERIN ${ }^{\mathrm{a} *}$

$7 \quad{ }^{a}$ INRA, UMR 1208, Ingénierie des Agropolymères et Technologies Emergentes, 2 Place Pierre

8 Viala, F-34060 Montpellier cedex1, France ; ${ }^{b}$ CIRAD, UMR 1208, Ingénierie des Agropolymères et

9 Technologies Emergentes, TA 40/16 73 Rue JF Breton 34398 Montpellier cedex 5, France ; ${ }^{\mathrm{I}}$ INRA, 10 U.R. 1264, Mycologie et Sécurité des Aliments, Domaine de la Grande Ferrade, 71 Av. Edouard 11 Bourleaux, BP 81, 33883 Villenave-d'Ornon cedex, France.

\footnotetext{
${ }^{*}$ Corresponding author. E-mail : lullien@ supagro.inra.fr
} 


\section{Abstract}

3 The milling behavior of two naturally infected samples of durum wheat grain with contrasting levels of

4 mycotoxins was studied. Although the two samples showed a similar milling behavior, an increase of about 5 twenty percent in deoxynivalenol (DON) levels was found in semolina from the sample containing the higher

6 level of mycotoxin. However, even if the highest concentration of DON was found in fractions originating

7 from the grain outer layers, the mycotoxin contamination in semolina and flours were not related to the 8 amount of two compounds (ash or phytic acid) that could be used as markers to monitor these external 9 tissues. The presence of the trichothecene-producing fungi in the most internal semolina fraction was also 10 shown using specific DNA primers and PCR amplification. Comparison of DON concentrations in the feed 11 stock and corresponding output at each milling step or grinding of semolina fractions followed by sizing 12 showed that concentration of the mycotoxin occurs in the finest particles at the first processing steps. 13 Therefore, DON contamination of the milling fractions is not simply due to the presence of peripheral grain 14 tissues.

16 Key words: deoxynivalenol (DON), durum wheat, Fusarium spp., milling, mycotoxin, Triticum. 


\section{Introduction}

2 Fusarium head blight (FHB) or scab is a worldwide disease of wheat (Triticum aestivum and 3 durum) and other small grain cereals which is caused by several Fusarium species (Parry et al. 4 1995; Bai et al. 2001). In Europe, Fusarium graminearum is one of the most frequently encountered 5 species on wheat (Goswami and Kistler 2004) mainly when wet and warm weather coincided with 6 the wheat anthesis and the beginning of grain filling (Bottalico and Perrone 2002; Champeil et al. 7 2004). This fungal disease leads to the formation of shrivelled, light test-weight kernels that reduce 8 grain yield and quality and affect milling yield (Edwards 2004).

9 In addition to grain yield loss due to FHB, production by Fusarium of toxic secondary metabolites 10 known as mycotoxins (Bennett and Klich 2003) may also impair the end-use of the harvested 11 cereals. One of these mycotoxins, deoxynivalenol (DON), which belongs to the trichothecene 12 (TCT) family could be considered as the most important wheat contaminant, as demonstrated by 13 surveys on its occurrence in grain (Bottalico and Perrone 2002). Its ingestion by animals was found 14 to lead to different symptoms depending on the sensitivity of species such as a decrease in weight 15 gain and nutritional efficiency, anorexic syndromes and altered immune function (Pestka 2007). 16 Due to its proved toxicity and its potential effect on the immune system, the European Community 17 have strictly fixed (EC regulation number 1881, 2006) the maximum DON authorized level in 18 unprocessed durum or common wheat grains at 1750 and $1250 \mu \mathrm{g} \cdot \mathrm{kg}^{-1}$ respectively and in resulting 19 flours or semolina at $750 \mu \mathrm{g} \cdot \mathrm{kg}^{-1}$.

20 Some control of DON contamination in the field could probably be obtained by the selection of 21 resistant cultivars (Gervais et al. 2003; Jiang et al. 2007) and a better knowledge of the 22 environmental factors which are involved (Edwards 2004; Koch et al. 2006). However, the 23 fractionation process, as one of the final steps leading to the cereal end-products, remains critical to 24 control the mycotoxin content in consumed fractions. If the first stages of Fusarium contamination appear to be limited to the grain outer layers (McKeehen et al. 1999), contamination may be 
1 reduced by the milling process that separates the endosperm from the bran containing these outer

2 layers, the fungi and the toxins could also be found in the endosperm (Kang and Buchenauer 1999;

3 Jackowiak et al. 2005) that leads to flours or semolina. Previous studies on durum wheat showed

4 that a significant reduction of the average DON level could be achieved at each step of the grain

5 processing (Nowicki et al. 1988; Dexter et al. 1997; Visconti et al. 2004; Manthey et al. 2004).

6 However, the relationship between these steps and the tissue origin of the different fractions have

7 not been investigated neither the effect of the level of contamination on the DON distribution.

8 In this paper, the grain characteristics and milling behavior at a semi-industrial scale of two 9 naturally infected samples of the same durum wheat cultivar but displaying distinctly different 10 levels of DON were analyzed. Furthermore, the impact of the milling process on the DON 11 distribution in the outcoming fractions was compared and discussed.

13 Material and methods

14 Wheat samples and grain characterization

15 Two samples of Triticum durum (Acalou cultivar) cultivated in France in 2003 were stored at $4^{\circ} \mathrm{C}$ 16 before milling.

17 Test weight and determination of Thousand Kernel Weight (TKW) determination were performed 18 respectively with standard AACC method 55-10 (AACC 2000) and ISO method ( $\mathrm{N}^{\circ} 520,1977$ ). 19 Grain vitreousness was assessed by analysis of kernel cross-sections (obtained with a Pohl kernel 20 cutter, Versuchs und Lehranstalt für Brauerei, Berlin, Germany) and expressed by the percentage of 21 vitreous versus mealy grains.

22 Particle Size Index (PSI) was determined according to the adapted AACC method 55-30 (AACC 23 2000). Twenty grams of each wheat sample were ground with a laboratory mill 3303 (Perten 24 Instruments $\mathrm{AB}$, Huddinge, Sweden) and the product obtained was sieved for $10 \mathrm{~min}$ using $75 \mu \mathrm{m}$ 25 sieve (LS-PRO, Hosokawa Alpine AG, Germany). The PSI corresponds to the percentage weight of 26 particles able to pass through the sieve. 


\section{$2 \quad$ Milling conditions}

3 Cleaned grain was tempered to $17 \%$ water content before milling. Durum wheat milling was 4 performed using a semi-industrial semolina mill $\left(150 \mathrm{~kg} \cdot \mathrm{h}^{-1}\right)$ as described before (Chaurand et al. 5 1999). It was equipped with four break rolls or four reduction rolls followed by sifters for sizing and 6 six sizing purifiers (Figure 1). This led to the production of four break flours (BF2 to BF5) and four 7 reduction flours (RF1 to RF4); six purified semolina (SE1 and SE3 which corresponds to the inner 8 endosperm, SE2 and SE4 originating from more external part of the endosperm compared with SE1 9 and SE3, SE5 and SE6 coming from the most peripheral part of the endosperm) and four bran or 10 middlings: coarse bran (CB), purified fine bran (PFB), sized fine bran (SFB), and shorts (SH). Each 11 fraction was collected and its yield expressed as weight percentage of the total milled grain amount. 12 Furthermore, an aliquot sample of the 14 feeding fractions from each roll or purifier were also 13 recovered. The collected fractions were stored at $4^{\circ} \mathrm{C}$.

$15 \quad$ Figure 1

\section{Biochemical analyses}

18 Water and ash content of the grain were determined in triplicate according to standard AACC 19 methods 44-19 and 08-12 respectively (AACC 2000). The phytic acid content was measured at 500 $20 \mathrm{~nm}$ from acidic extract of ground grains or milling fractions using a colorimetric method described 21 by Latta and Eskin (1980) and modified by Vaintraub and Lapteva (1988). A standard curve was 22 obtained with corn phytate (P-8810, Sigma-Aldrich, St Quentin Fallavier, Fr.) solutions of known 23 concentrations. 
1

\section{DON measurement}

All the fractions were homogenized before their division to obtain a representative sample and eventually ground in order to reduce the particle size below $500 \mu \mathrm{m}$. DON was then extracted at room temperature with $100 \mathrm{~mL}$ of $84 \%(\mathrm{v} / \mathrm{v})$ acetonitrile in water using $25 \mathrm{~g}$ of each fractions except for bran and middling fractions which allowed the amount to be reduced to $15 \mathrm{~g}$. The mixture was shaken $30 \mathrm{~min}$ and homogenized with an Ultra Turrax ${ }^{\circledR}$ for 3 min. After filtering through Whatman ${ }^{\circledR}$ No. 1 filter paper, $8 \mathrm{~mL}$ of the filtrate were passed through a Mycosep® 225 column (Romer Labs., Union, MO, USA). The recovered purified solution (4 mL) was transferred to a new vial and the solvent evaporated to dryness under a stream of nitrogen at $50^{\circ} \mathrm{C}$. The dry residue was then stored in a tightly closed glass bottle at $-20^{\circ} \mathrm{C}$ until use or suspended in $500 \mu \mathrm{L}$ of methanol $20 \%(\mathrm{v} / \mathrm{v})$ and centrifuged (20000g, $6 \mathrm{~min})$ before RP-HPLC analysis.

The DON extract $(50 \mu \mathrm{L})$ was injected on a NovaPak ${ }^{\circledR} \mathrm{C}_{18}$ column $(60 \AA, 4 \mu \mathrm{m}, 150 \times 3.6 \mathrm{~mm}$, Waters SAS, Guyancourt, Fr.) and equilibrated with $7 \%(\mathrm{v} / \mathrm{v})$ acetonitrile at a flow rate of 0.7 $\mathrm{mL} \cdot \mathrm{min}^{-1}$. Elution was obtained by increasing the acetonitrile concentration in water to $80 \%$ after $1515 \mathrm{~min}$. DON was detected at $218 \mathrm{~nm}$ with a 2487 dual $\lambda$ UV detector (Waters SAS, Guyancourt,

16 Fr.). Commercial DON (Sigma-Aldrich, St Quentin Fallavier, Fr) was used to prepare calibration standards ranging from 0.1 to $1 \mu \mathrm{g} \cdot \mathrm{mL}^{-1}$. To assess a calibration curve with the standards, a linear regression was fitted on the data. DON concentration in the extracts were computed from the regression curve. Mean DON recovery was estimated at $98.5 \%$ with a $5.9 \%$ coefficient of variation from a wheat standard flour sample (FAPAS, T2210, with an average concentration of 463 $\left.\mu \mathrm{g} . \mathrm{kg}^{-1}\right)$ and based on triplicate measurement on four distinct extractions.

\section{Detection of TCT-producing Fusarium spp.}

DNA was extracted from ground grains $(200 \mathrm{mg})$ or milling fractions with the DNeasy® Plant Mini Kit from Qiagen (Qiagen S.A., Les Ulis, Fr.) according to the manufacturer instructions. All PCR amplifications were carried out in $50 \mu \mathrm{l}$ with 1 ng of DNA template. Reactions mixtures 
1 contained 25 pmoles of each primers (Tox5-1: 5'-GCTGCTCATCACTTTGCTCAG; Tox5-2: 5'-

2 CTGATCTGGTCACGCTCCATC) defined according to previous studies (Niessen and Vogel 3 1998), $2.5 \mathrm{U}$ of DNA polymerase (Invitrogen Co., Cergy-Pontoise, Fr.), $400 \mu \mathrm{M}$ of each 4 deoxynucleotide triphosphate (Promega, Charbonnières, Fr.). Reactions were performed using the 5 following PCR conditions: denaturation at $95^{\circ} \mathrm{C}$ for $1 \mathrm{~min} 30,40$ cycles of denaturation at $95^{\circ} \mathrm{C}$ for $630 \mathrm{~s}$, annealing at $55^{\circ} \mathrm{C}$ for $40 \mathrm{~s}$ and extension at $72^{\circ} \mathrm{C}$ for $30 \mathrm{~s}$, final extension at $72^{\circ} \mathrm{C}$ for $5 \mathrm{~min}$, 7 followed by cooling at $4^{\circ} \mathrm{C}$. Amplification products were analysed on a $1 \%$ agarose gel stained with 8 ethidium bromide. Genomic DNA extracted from the fungi $F$. graminearum was kindly given by L. 9 Pinson-Gadais (INRA, Bordeaux).

\section{Results and discussion}

Wheat characterization and milling behavior

Two durum wheat samples from the cultivar Acalou were selected as their levels of natural contamination with DON were found to be different. The first sample $(A l)$ was found to contain $382 \mu \mathrm{g} . \mathrm{kg}^{-1}$ (d. m.) of DON and thus could be considered acceptable in accordance to the European 17 Community legislation whereas the other (A2) displayed a DON level around $4203 \mu \mathrm{g} \cdot \mathrm{kg}^{-1}$ (d. m.).

Table 1

Table 1 clearly illustrates that even if the DON level in $A 2$ is more than ten fold higher than that in A1, no apparent differences between grain characteristics of the two wheat grain samples were observed. As these samples shared common grain characteristics, it was interesting to compare their milling behavior, deoxynivalenol concentration and distribution in the generated fractions. The 
1 yield of each fraction obtained after grain milling at a semi-industrial scale $\left(150 \mathrm{~kg} \cdot \mathrm{h}^{-1}\right.$, milling

2 scheme in Figure 1) are summarized in Table 2. Even if the samples displayed a different level of 3 toxin, which could either be due to a different growth of the fungi or a distinct toxin production 4 level, no drastic changes were observed between the milling yields of the different fractions from 5 both of the samples, taking into account the coefficient of variation.

6

7 Table 2 
2 Table 3

3 A distinct distribution of the total amount of DON in the milling fractions was obtained depending

4 on the wheat sample. Indeed, in the most contaminated grain sample, the highest toxin proportion

5 was found in semolina whereas, in the less contaminated sample, this highest toxin proportion was

6 found in bran and shorts. Two hypotheses could explain this difference in DON distribution: a

7 higher friability of the outer layers in the most contaminated grain sample or a higher amount of

8 toxin in the endosperm of these grains. In order to test a potential link between the increase of DON

9 proportion in semolina and contamination of this milling fraction with the outer layers, ash and

10 DON concentrations in semolina and flours were analyzed and compared (Figure 2).

12 Figure 2

$2627.0 \mathrm{mg} . \mathrm{g}^{-1} \mathrm{~d}$.m. from BF2 to BF5 and between 15.2 to $34.6 \mathrm{mg} \cdot \mathrm{g}^{-1} \mathrm{~d} . \mathrm{m}$. from RF1 to RF4). 
1 Therefore, the observed higher DON concentration in flours from the first break and reduction rolls

2 compared to the last ones was not only due to a contamination with the grain outer layers but rather

3 resulted from highly infected particles obtained at the first steps of grain breaking. Production of

4 these fine particles from infected parts of the endosperm could be generated by the fungus

5 penetration and by degradation of this tissue as already suggested for common wheat (Seitz et al.

$61985)$.

7

$8 \quad$ Fusarium detection in the milling fractions

9 In order to monitor the TCT-producing Fusarium species, DNA extraction was performed from 10 each type of milling fractions and amplified by PCR. The primers used for amplification were 11 derived from the gene Tri5 encoding the first enzyme (trichodiene synthase) involved in the TCT 12 biosynthetic pathway, that was already been demonstrated to be a pertinent probe to track TCT13 producing fungi (Niessen and Vogel 1998). Results of the PCR amplification, reported in Figure 3, 14 revealed the expected specific fragment (658 bp).

$16 \quad$ Figure 3

18 All of the analyzed fractions were found to contain TCT-producing fungi. A higher amount of 19 fungi appeared in the fractions enriched in the grain peripheral tissues, such as coarse bran (CB) and 20 other bran and short fractions. But semolina coming out from the inner endosperm (SE1 and SE3) 21 was also found to contain TCT-producing fungi. These data are in accordance with previous results 22 obtained by Pinson-Gadais et al. (2007) however in a distinct durum wheat cultivar. Furthermore, 23 the fractions from the most contaminated grains also appeared to contain a higher amount of fungi. 24 Therefore, DON contamination in semolina could be due to the toxin production by fungi inside the 25 endosperm tissue. 


\section{Relationship between roll and purifier feedings and corresponding outputs}

2 In order to clarify the DON distribution along milling, DON concentration in the feedings from all 3 rolls and purifiers were determined and summarized in Table 4. BR2 corresponds to meal fraction 4 obtained after the two first break rolls, BR3 to BR5 are the feedings corresponding to the following 5 break rolls, SP1 to SP6 are the feedings from the first to the sixth purifiers and RR1 to RR4 are the 6 feedings from the first to the fourth reduction rolls (Figure 1).

7

8 Table 4

9

$21 \quad$ Table 5

13 concentration in semolina was always found lower than those of the corresponding feedings 14 (ranging from identical to two or three-fold less concentrated), the ratio between break and

15 reduction flours and the corresponding feedings decreased from the first to the last step of the 16 milling process. Indeed, the DON concentrations were found to be 1.5 to 3 -fold higher in the first 17 break and reduction flours compared to the corresponding feedings. Thus, at the first breaking and 18 reduction steps of the milling process, DON appeared to be concentrated in the flours, i.e. particles 19 with the smallest size.

23 In order to test the hypothesis that grain breaking or endosperm reduction at the first milling steps 24 could lead to a preferential DON concentration in the finest fractions, the semolina SE3 and SE1 25 (originating from the most internal part of the grain) from sample $A 2$ were sifted. Comparison 
1 between dry mass of the sifted semolina and their respective DON concentration showed that the 2 highest DON concentration occurred in the finest fractions (Table 5, a1, b1).

3 Each semolina was then ground, after removal of the finest particles (i.e. particles under $315 \mu \mathrm{m}$ 4 for SE3 which accounted for $4 \%$ of the semolina dry mass and displayed a DON concentration of $53358 \mu \mathrm{g} . \mathrm{kg}^{-1}$; particles under $450 \mu \mathrm{m}$ for SE1 which accounted for $26 \%$ of the semolina dry mass 6 and displayed a DON concentration of $\left.4151 \mu \mathrm{g} \cdot \mathrm{kg}^{-1}\right)$. The resulting grinded material was classified 7 by size in order to analyze the DON concentration and distribution in each of the obtained fractions. 8 Table 5 (a2, b2) clearly shows that DON concentration was again higher ( 3 to 5 fold) in the fraction 9 characterized by the finest particle size.

10 Moreover, analysis of the DON amount distribution after semolina grinding and sizing compared 11 to those of the dry mass showed that DON amount in the largest size fractions was less than a half 12 the amount expected if DON was equally distributed in the material. In contrast, fractions 13 corresponding to the smallest particles concentrated the toxin with an about two fold factor 14 compared to the expected level.

15 Therefore, absence of relationships between DON contamination of flours and semolina and the 16 ash and phytic acid contents, as well as evidence of DON concentration in the finest particles from 17 the endosperm (Table 5) could explain the unexpected distribution of DON in the milling fractions. 18 It thus revealed that contamination of semolina or flours could not only be originated from the grain 19 outer layers but also from other contaminated parts of the grain that were shown to be friable. It 20 appeared particularly significant for grains containing a high level of mycotoxin and for fractions 21 coming out from the first steps of the process. Thus, higher DON level in the finest particles from 22 the semolina fraction of the most infected wheat sample could result from a deeper fungi 23 penetration in grains or a higher damage of the grain internal structure due to an increased synthesis 24 of hydrolytic enzymes, that are known to be produced by Fusarium (Jackowiak et al 2005). 25 However, further works are needed to test this hypothesis and examine if it is also observed for 26 other durum wheat cultivars. Nevertheless, these studies point out the interest to control the 
1 generation and distribution of the finest particles during milling, in order to lower the DON amount 2 in semolina. This could be potentially achieved by improving the sizing efficiency of the sifters 3 after the two first break rolls or by increasing the efficiency of the first two sizing purifiers in order 4 to better eliminate the finest particles at the first milling steps even if this will results in a decrease 5 of the semolina yield. Indeed as semolina are the fractions used for pasta making, this control could 6 constitute a key factor in order to reduce the DON level in corresponding consumed wheat products. 7

8 Acknowledgments

9 Authors would like to thank G. Maraval (INRA, Montpellier), C. Ducos and L. Pinson-Gadais 10 (INRA, Bordeaux) for their technical assistance and advices. This work was financially supported 11 by the European Commission through MYCOTOX project (ICA4-CT-2002-10043), the French 12 Ministry for Research through RARE project and the Chilean MECESUP 0202 and University of 13 Concepción (G. Rios grant). 
1

2

3

4

4

\section{References}

AACC. 2000. Approved Methods. 10th ed. Minnesota (US): American Association of Cereal Chemists.

Bai GH, Plattner R, Desjardins A, Kolb F. 2001. Resistance to Fusarium head blight and deoxynivalenol accumulation in wheat. Plant Breeding. 120: 1-6.

Bennett JW, Klich M. T. 2003. Mycotoxins. Clin. Microbiol. Rev. 16: 497-516.

Bottalico A, Perrone G. 2002. Toxigenic Fusarium species and mycotoxins associated with head blight in small-grain cereals in Europe. Eur. J. Plant Pathol. 108: 611-624.

Champeil A, Doré T, Fourbet JF. 2004. Fusarium head blight: epidemiological origin of the effects of cultural practices on head blight attacks and the production of mycotoxins by Fusarium in wheat grains. Plant Sci. 166: 1389-1415.

Chaurand M, Lempereur I, Roulland TM, Autran JC, Abecassis J. 1999. Genetic and agronomic effects on semolina milling value of durum wheat. Crop Sci. 39: 790-795.

Dexter JE, Marchylo BA, Clear RM, Clarke JM. 1997. Effect of Fusarium head blight on semolina milling and pasta-making quality of durum wheat. Cereal Chem. 74: 519-525.

Edwards SG. 2004. Influence of agricultural practices on Fusarium infection of cereals and subsequent contamination of grain by trichothecene mycotoxins. Toxicol. Lett. 153: 29-35.

18 Gervais L, Dedryver F, Morlais JY, Bodusseau V, Negre S, Bilous M, Groos C, Trottet M. 2003. 19 Mapping of quantitative trait loci for field resistance to Fusarium head blight in an European 20 winter wheat. Theor. Appl. Genet. 106: 961-970.

21 Goswami RS, Kistler HC. 2004. Heading for disaster: Fusarium graminearum on cereal crops. Mol. 22 Plant Pathol. 5: 515-525.

23 Greffeuille V, Abecassis J, Bar Lhelgouach C, Lullien-Pellerin V. 2005. Differences in the aleurone 24 layer fate between hard and soft common wheats at grain miling. Cereal Chem. 82: 138-143.

Jackowiak H, Packa D, Wiwart M, Perkowski J. 2005. Scanning electron microscopy of Fusarium damaged kernels of spring wheat. Int. J. of Food Microbiol. 98: 113-123. 
1 Jiang G-L, Dong Y, Shi J, Ward RW. 2007. QTL analysis of resistance to Fusarium head blight in

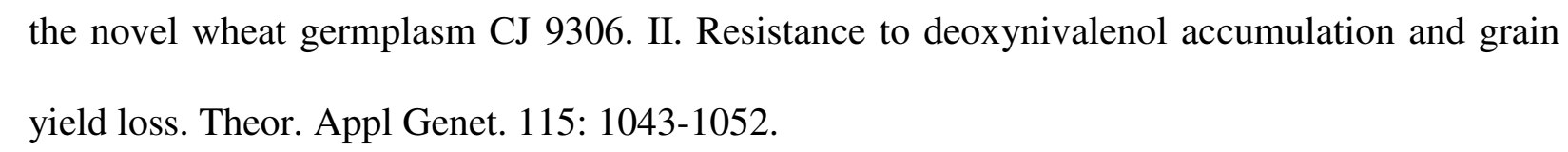

Kang Z, Buchenauer H. 1999. Immunocytochemical localization of fusarium toxins in infected wheat spikes by Fusarium culmorum. Physiol. and Mol. Plant Pathol. 55: 275-288.

Koch HJ, Pringas C, Maerlaender B. 2006. Evaluation of environmental and management effects on Fusarium head blight infection and deoxynivalenol concentration in the grain of winter wheat. Europ. J. of Agron. 24: 357-366.

Latta M, Eskin M. 1980. A simple and rapid colorimetric method for phytate determination. J. Agric. Food Chem. 28: 1313-1315.

Manthey FA, Wolf-Hall CE, Yalla S, Vijayakumar C, Carlson D. 2004. Microbial loads, mycotoxins, and quality of durum wheat from the 2001 harvest of the Northern Plains region of the United States. J. Food Prot. 67: 772-780.

McKeehen JD, Busch RB, Fulcher RG. 1999. Evaluation of wheat (Triticum aestivum L.) phenolic acids during grain development and their contribution to Fusarium resistance. J. Agric. Food Chem. 47: 1476-1482.

Niessen ML, Vogel RF. 1998. Group specific PCR-detection of potential trichothecene producing Fusarium species in pure cultures and cereal samples. Syst. Appl. Microbiol. 21: 618 - 31.

Nowicki TW, Gaba DG, Dexter JE, Matsuo RR, Clear RM. 1988. Retention of the Fusarium mycotoxin deoxynivalenol in wheat during processing and cooking of spaghetti and noodles. J. Cereal Sci. 8: 189-202.

Parry DW, Jenkinson P, McLeod L. 1995. Fusarium ear blight (scab) in small grain cereals, a review. Plant Pathol. 44: 207-238.

Pestka JJ. 2007. Deoxynivalenol: Toxicity, mechanisms and animal health risks. Anim. Feed Sci. and Technol. 137: 283-298.

Pinson-Gadais L, Barreau C, Chaurand M, Gregoire S, Monmarson M, Richard-Forget F. 2007. 
1 Distribution of toxinogenic Fusarium spp. and mycotoxin production in milling fractions of 2 durum wheat. Food Additiv. and Contam. 24: 53-62.

3 Seitz LM, Yamazaki WT, Clements RL, Mohr HE, Andrews L. 1985. Distribution of

4 deoxynivalenol in soft wheat mill streams. Cereal Chem. 62: 467-469.

5 Vaintraub IA, Lapteva NA. 1988. Colorimetric determination of phytate in unpurified extracts of 6 seeds and the products of their processing. Anal. Biochem. 175: 227-230.

7 Visconti A, Haidukowski EM, Pascale M, Silvestris M. 2004. Reduction of deoxynivalenol during 8 durum wheat processing and spaghetti cooking. Toxicol. Lett. 153: 181-189. 


\begin{abstract}
1 Figure captions
2

3 Figure 1: Milling diagram of the semi industrial pilot mill (INRA, Montpellier). BR1 to BR5 are

4 feedings of break rolls, BF2 to BF5 are corresponding break flours, SP1 to SP6 are feedings of 5 purifiers, SE1 to SE6 are semolina; RR1 to RR4 are feedings of reduction rolls, RF1 to RF4 are 6 reduction flours, $\mathrm{CB}, \mathrm{PFB}$ and $\mathrm{SFB}$ are respectively coarse bran, purified fine bran and sized fine 7 bran, $\mathrm{SH}$ are shorts.
\end{abstract}

9 Figure 2: Comparison of DON (mg. $\mathrm{kg}^{-1} \mathrm{~d}$. m.) and ash (\% d. m.) concentration in the milling 10 fractions (except brans and shorts) from the two durum wheat samples (means of two replicates).

Figure 3 : Detection of TCT-producing fungi in grains and milling fractions from durum wheat Acalou samples $A 1$ and $A 2$ after PCR with primers derived from the gene encoding trichodiene 14 synthase. F. graminearum corresponds to DNA extracted from the fungus. ST are total semolina, 15 SE1 and SE3 are semolina from the most inner part of the endosperm, BF2 are the first break flours, $16 \mathrm{RF} 1$ are the first reduction flours, CB, SH, SFB and PFB are respectively coarse bran, shorts, sized 17 fine bran and purified fine bran. 

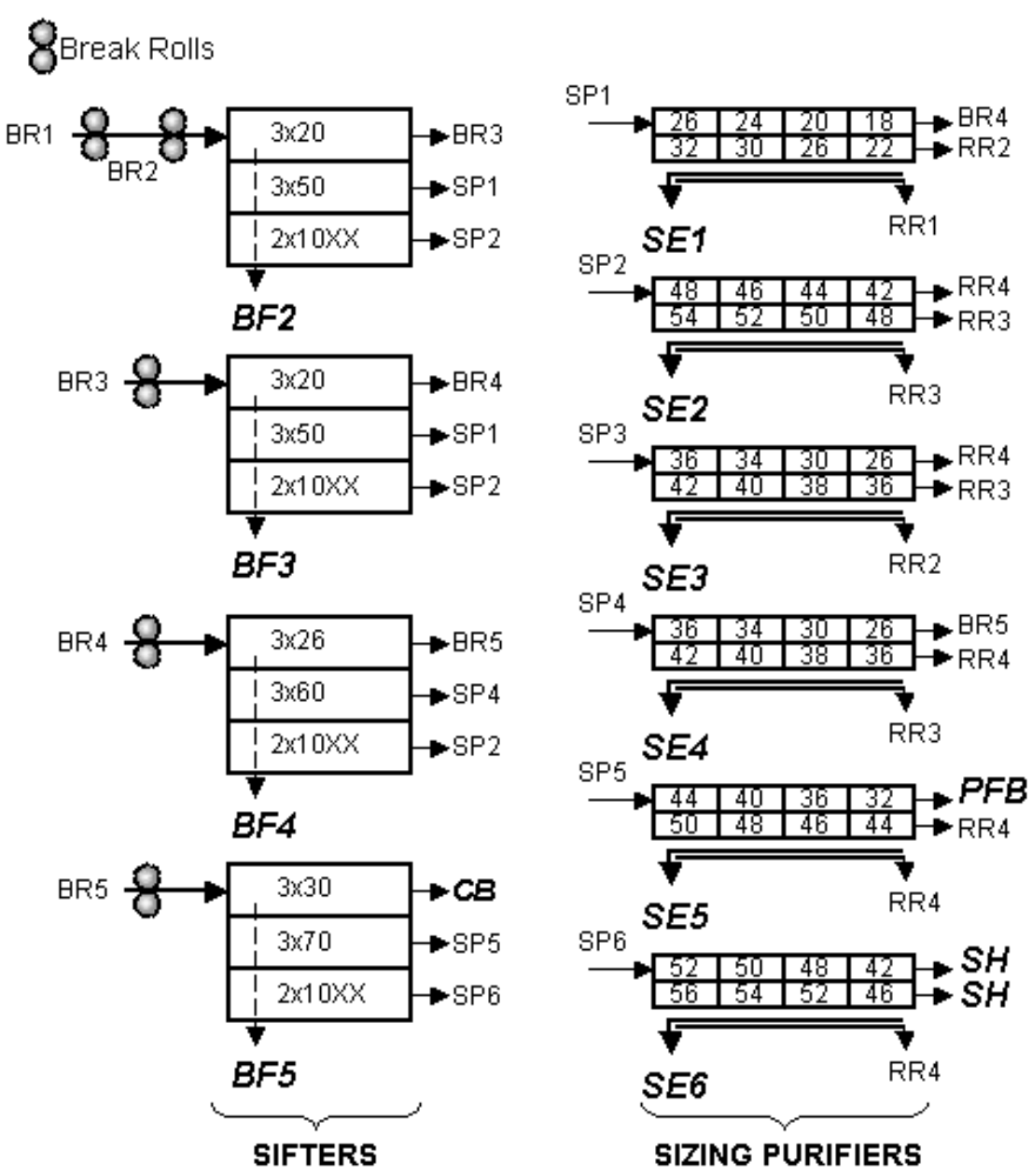

8 Reducing Rolls
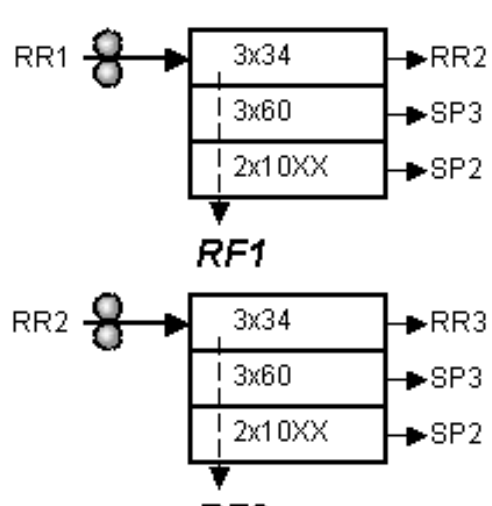
RF2

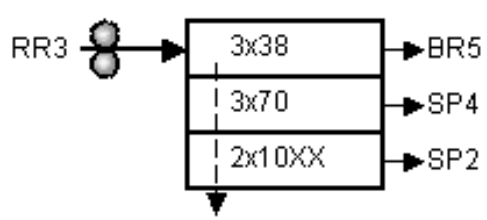

RF3

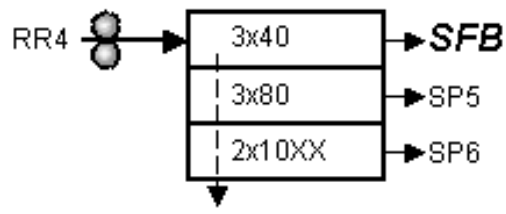

RF4

SIFTERS 




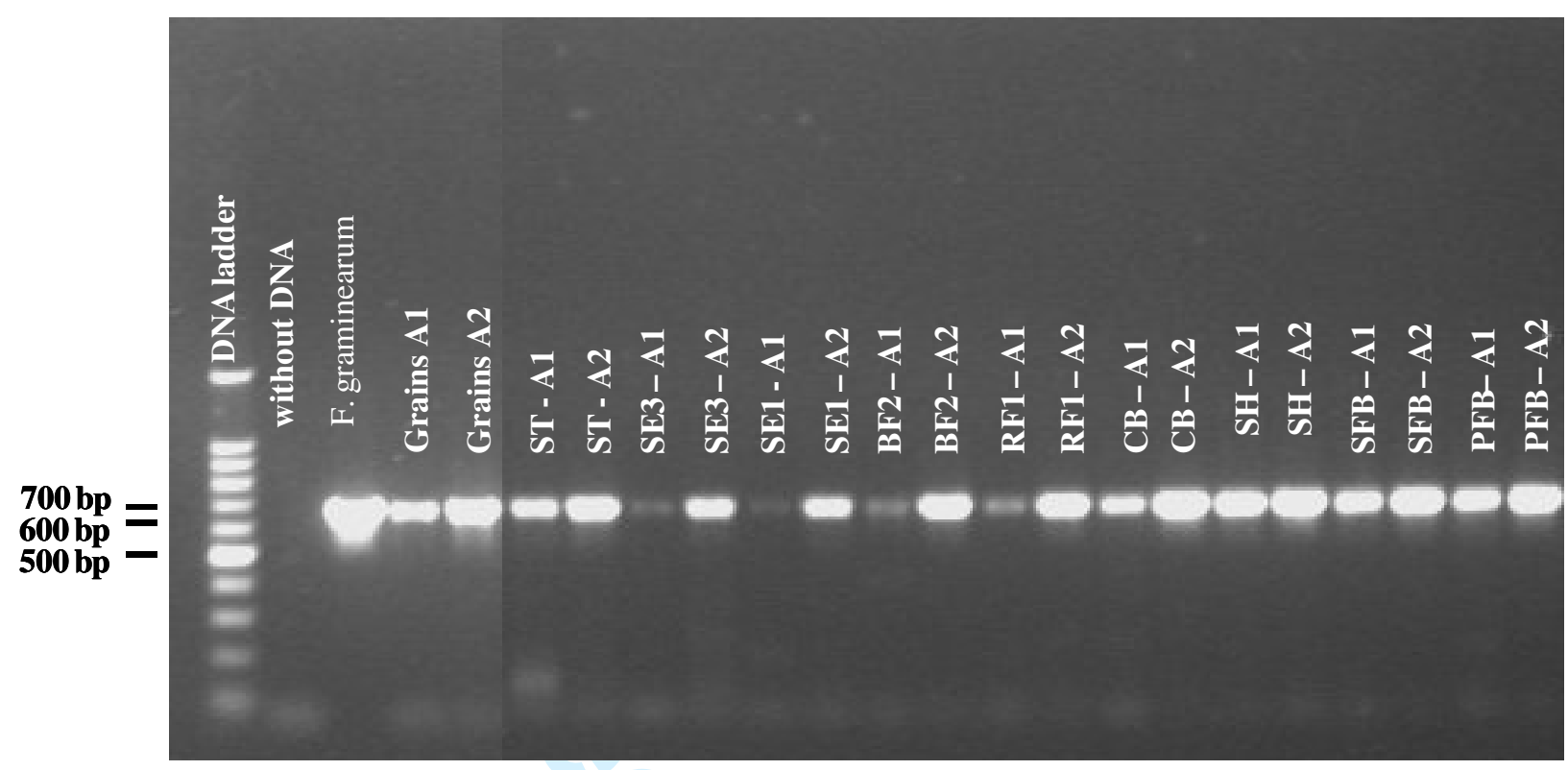


Table 1: Main physical characteristics and total DON concentration of the analyzed Acalou wheat samples naturally infected with Fusarium $^{a}$.

\begin{tabular}{lcc}
\hline \multicolumn{1}{c}{ Samples } & $\boldsymbol{A 1}$ & $\boldsymbol{A 2}$ \\
\hline DON $\left(\mu \mathrm{g} . \mathrm{kg}^{-1} \mathrm{~d} . \mathrm{m}.\right)$ & $382.0 \pm 9.7$ & $4203.5 \pm 202.7$ \\
Test weight $\left(\mathrm{kg} . \mathrm{hL}^{-1}\right)$ & $84.5 \pm 0.1$ & $84.3 \pm 0.1$ \\
TKW $(\mathrm{g})$ & $52.0 \pm 0.6$ & $50.0 \pm 0.7$ \\
Vitreousness $(\%)$ & 95.3 & 95.3 \\
PSI $(\%)$ & $5.1 \pm 0.1$ & $5.3 \pm 0.1$ \\
Water content $(\%)$ & $12.16 \pm 0.01$ & $12.33 \pm 0.02$ \\
\hline
\end{tabular}

${ }^{a}$ Values are means and standard deviation of three replicates. 
Table 2: Yield and DON concentration in the different milling fractions from the two durum wheat samples.

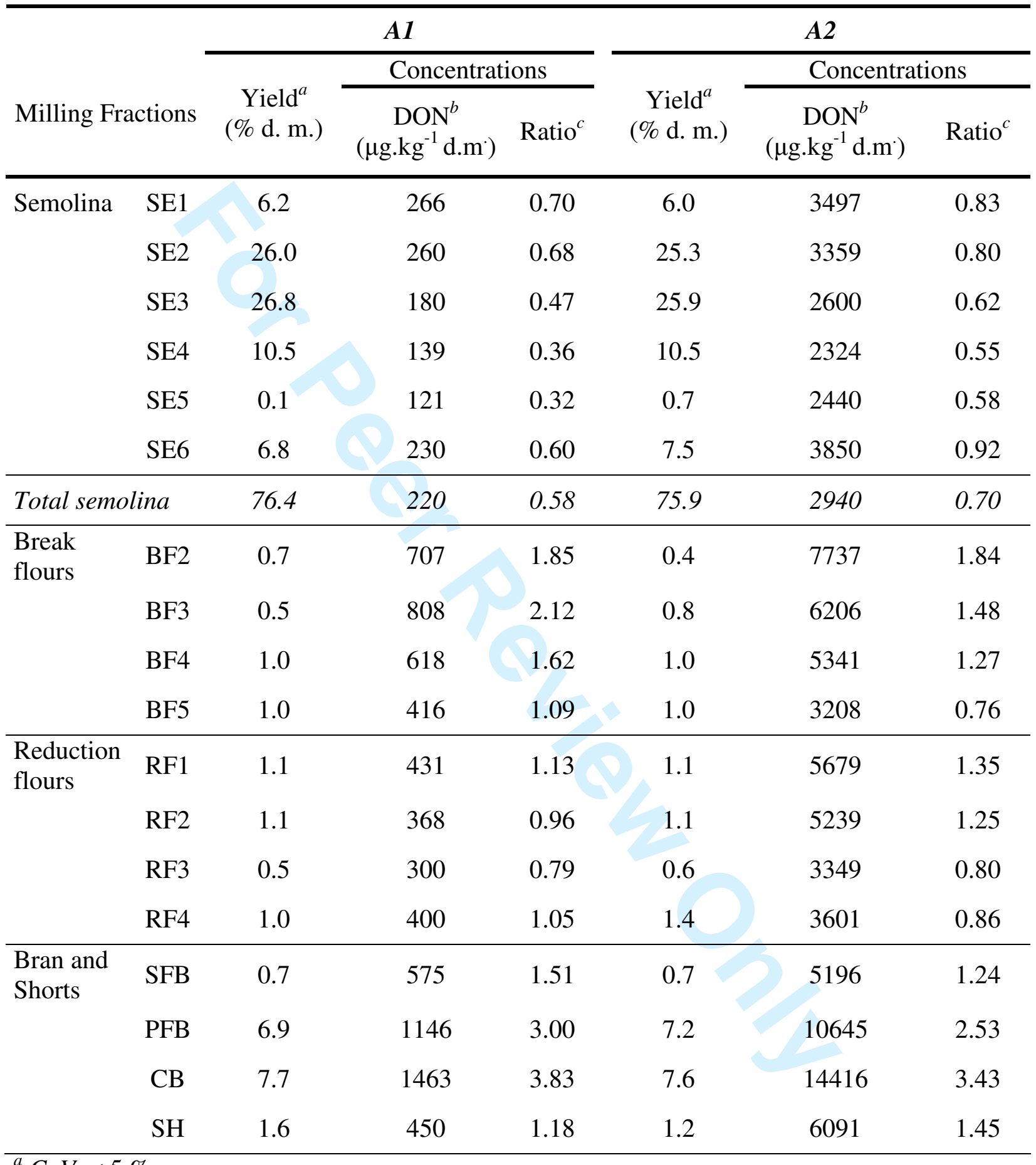

${ }^{a} C . V .<5 \%$.

${ }^{b}$ means of two replicates, $C . V .<5 \%$ for semolina and flours and $<10 \%$ for brans and shorts.

${ }^{c}$ Ratio between DON concentrations in the analyzed fraction versus those in cleaned grains. 
Table 3: Comparison of yield and DON distribution in percent of the total grain mass or DON total content.

\begin{tabular}{lccccc}
\hline \multirow{2}{*}{ Milling Fractions } & \multicolumn{2}{c}{$A 1$} & & \multicolumn{2}{c}{$A 2$} \\
\cline { 2 - 3 } \cline { 5 - 6 } \cline { 5 - 6 } & $\begin{array}{c}\text { Yield }^{a} \\
(\% \text { d.m. })\end{array}$ & $\begin{array}{c}\text { DON }^{b} \\
(\% \text { d.m. })\end{array}$ & & $\begin{array}{c}\text { Yield }^{a} \\
(\% \text { d.m. })\end{array}$ & $\begin{array}{c}\text { DON }^{b} \\
(\% \text { d.m. })\end{array}$ \\
\hline Total Semolina & 76.4 & 40.8 & & 75.9 & 49.6 \\
Total Break Flours & 3.2 & 4.8 & & 3.3 & 3.7 \\
Total Reduction Flours & 3.7 & 3.5 & & 4.2 & 4.1 \\
Total Brans and Shorts & 16.8 & 50.8 & & 16.6 & 42.6 \\
\hline
\end{tabular}

${ }^{a}$ Total yield was obtained from Table 2 .

${ }^{b}$ calculated taking into account the fraction yield and DON concentration and expressed as a percentage of the total amount of DON in the sample. 
Table 4: DON concentration ( $\mu \mathrm{g} \cdot \mathrm{kg}^{-1}$ d.m.) in the feedings of rolls and purifiers and ratio between DON concentrations in flours or semolina (reported in Table 2) versus those in the feedings.

\begin{tabular}{|c|c|c|c|c|c|}
\hline \multirow[b]{2}{*}{ Fractions } & & \multicolumn{2}{|c|}{$A 1$} & \multicolumn{2}{|c|}{$A 2$} \\
\hline & & $\mathrm{DON}^{a}$ & Ratio & $\mathrm{DON}^{a}$ & Ratio \\
\hline \multirow[t]{4}{*}{$\begin{array}{l}\text { Break roll } \\
\text { feedings }\end{array}$} & BR2 & 250 & 2.83 & 4891 & 1.58 \\
\hline & BR3 & 369 & 2.19 & 5865 & 1.06 \\
\hline & BR4 & 300 & 2.06 & 5946 & 0.90 \\
\hline & BR5 & 594 & 0.70 & 8571 & 0.37 \\
\hline \multirow[t]{6}{*}{$\begin{array}{l}\text { Sizing purifier } \\
\text { feedings }\end{array}$} & SP1 & 262 & 1.01 & 4476 & 0.78 \\
\hline & SP2 & 352 & 0.74 & 4343 & 0.77 \\
\hline & SP3 & 200 & 0.90 & 3563 & 0.73 \\
\hline & SP4 & 201 & 0.69 & 3477 & 0.67 \\
\hline & SP5 & 320 & 0.38 & 5747 & 0.42 \\
\hline & SP6 & 349 & 0.66 & 4143 & 0.93 \\
\hline \multirow[t]{4}{*}{$\begin{array}{l}\text { Reduction roll } \\
\text { feedings }\end{array}$} & RR1 & 242 & 1.78 & 2719 & 2.09 \\
\hline & RR2 & 248 & 1.48 & 3450 & 1.52 \\
\hline & RR3 & 401 & 0.75 & 3561 & 0.94 \\
\hline & RR4 & 312 & 1.28 & 4640 & 0.78 \\
\hline
\end{tabular}

\footnotetext{
${ }^{a}$ means of two replicates, $C . V .<7 \%$.
} 
Table 5: Distribution in dry mass (\% d.m.), DON concentration ( $\mu \mathrm{g} . \mathrm{kg}^{-1}$ d.m.) and DON distribution (\%) in sieved fractions from semolina SE3 or SE1 of the wheat sample $A 2$ before $(\mathrm{a} 1, \mathrm{~b} 1)$ and after $(\mathrm{a} 2, \mathrm{~b} 2)$ grinding. DON concentration of each analyzed fraction was specified in brackets at the top of each table.

a1

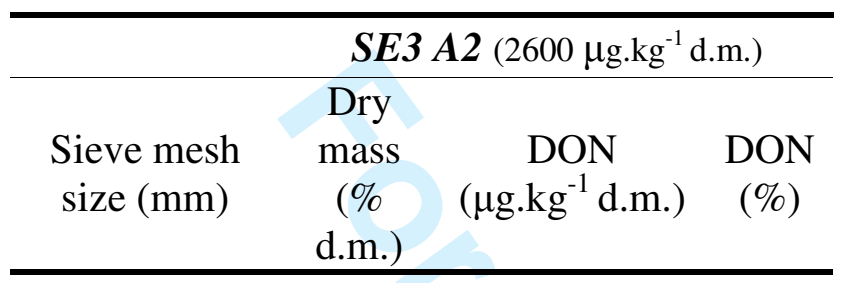

\begin{tabular}{cccc}
\hline$>0.560$ & 8 & 2089 & 7 \\
$0.560-0.450$ & 31 & 2285 & 28 \\
$<0.450$ & 61 & 2716 & 66 \\
\hline
\end{tabular}

b1

\begin{tabular}{|c|c|c|c|}
\hline & \multicolumn{3}{|c|}{ SE1 A2 $\left(3496 \mu\right.$ g.kg ${ }^{-1}$ d.m. $)$} \\
\hline $\begin{array}{l}\text { Sieve mesh } \\
\text { size }(\mathrm{mm})\end{array}$ & $\begin{array}{c}\text { Dry } \\
\text { mass } \\
(\% \\
\text { d.m. })\end{array}$ & $\begin{array}{c}\text { DON } \\
\left(\mu \mathrm{g} . \mathrm{kg}^{-1} \text { d.m. }\right)\end{array}$ & $\begin{array}{c}\text { DON } \\
(\%)\end{array}$ \\
\hline
\end{tabular}

\begin{tabular}{cccc}
$>0.630$ & 24 & 2418 & 18 \\
$0.630-0.560$ & 32 & 2956 & 29 \\
$<0.560$ & 44 & 3912 & 53 \\
\hline
\end{tabular}

a2

\begin{tabular}{|c|c|c|c|}
\hline & \multicolumn{3}{|c|}{ SE3 A2 (2300 $\mu$ g.kg ${ }^{-1}$ d.m. $)$} \\
\hline $\begin{array}{l}\text { Sieve mesh } \\
\text { size }(\mathrm{mm})\end{array}$ & $\begin{array}{c}\text { Dry } \\
\text { mass } \\
(\% \\
\text { d.m. })\end{array}$ & $\begin{array}{c}\mathrm{DON} \\
\left(\mu \mathrm{g} \cdot \mathrm{kg}^{-1} \mathrm{~d} \cdot \mathrm{m} .\right)\end{array}$ & $\begin{array}{c}\text { DON } \\
(\%)\end{array}$ \\
\hline$>0.200$ & 26 & 967 & 11 \\
\hline $0.100-0.200$ & 28 & 1555 & 19 \\
\hline$<0.100$ & 43 & 3682 & 69 \\
\hline
\end{tabular}

b2

SE1 A2 $\left(3189 \mu \mathrm{g} \cdot \mathrm{kg}^{-1}\right.$ d.m. $)$

Dry

Sieve mesh mass DON DON

size $(\mathrm{mm}) \quad\left(\% \quad\left(\mu \mathrm{g} . \mathrm{kg}^{-1} \mathrm{~d} . \mathrm{m}.\right)\right.$

$(\%)$

d.m.)

\begin{tabular}{llll}
\hline \multicolumn{3}{c}{ d.m.) } & \\
$>0.315$ & 31 & 1087 & 11 \\
$0.160-0.315$ & 30 & 1863 & 18 \\
$<0.160$ & 39 & 5736 & 71 \\
\hline
\end{tabular}

